\title{
Fervidicella metallireducens gen. nov., sp. nov., a thermophilic, anaerobic bacterium from geothermal waters
}

\author{
Christopher D. Ogg and Bharat K. C. Patel
}

Correspondence

Bharat K. C. Patel

b.patel@griffith.edu.au
Microbial Gene Research and Resources Facility, School of Biomolecular and Physical Sciences, Griffith University, Brisbane, OLD 4111, Australia
The Great Artesian Basin (GAB) underlies more than one-fifth of the Australian continent, an area over $1.7 \times$ $10^{6} \mathrm{~km}^{2}$, and is considered to be the largest geothermal subsurface aquifer in the world, with a water-storage capacity of $8.7 \times 10^{12} \mathrm{~m}^{3}$ (Habermehl, 1980). The GAB was formed between 100 and 250 million years ago and contains groundwaters that are estimated to be 2 million years old. It is composed of at least four alternating layers of water-bearing permeable sandstone aquifers and nonwater-bearing impermeable shale, the sequence of which can be found up to $3000 \mathrm{~m}$ deep. The GAB groundwaters are heated by the Earth's magma due to the aquifer's great depth, and flow from the recharge areas at the edge of the

Abbreviation: GAB, Great Artesian Basin.

The GenBank/EMBL/DDBJ accession number for the $16 \mathrm{~S}$ rRNA gene sequence of strain $\mathrm{AeB}^{\top}$ is FJ481102. basin to the discharge areas in central Australia as mound springs at an estimated rate of $1-5 \mathrm{~m}_{\text {year }}{ }^{-1}$. Chemically, GAB groundwaters can be bicarbonate-, chloride-, sulfateor iron-rich depending on the surrounding geological formations. The GAB is tapped by more than 5000 freeflowing bores, with source temperatures ranging between 30 and $100{ }^{\circ} \mathrm{C}$, which provide a vital water resource to outback communities to support agricultural, industrial and domestic activities. The varying temperatures, chemical compositions and the slow flow rate of GAB groundwaters provide a conducive environment for a wide diversity of microbial habitats. Distinct, macroscopic microbial mat communities thrive at specific temperatures along the temperature gradient created as flowing borewaters cool to ambient temperatures in open drain run-off channels, which often stretch hundreds of kilometres to rehydrate livestock. Previous culture-independent analyses 
of four microbial mat communities existing in the New Lorne Bore (registered bore number 17263) at temperatures between 52 and $75{ }^{\circ} \mathrm{C}$ indicated the presence of species spanning the full diversity of domain 'Bacteria', including a diverse range of as-yet-uncultured novel organisms (Spanevello, 2001). Recent culture-dependent studies of these microbial mats have focused on thermophilic metal-reducers (Ogg \& Patel, 2009a, b, c; Ogg et al., 2010), which have a significant influence on the geochemistry of deep subsurface aquifers through their cycling of metals, particularly $\mathrm{Fe}(\mathrm{III})$ and $\mathrm{Mn}(\mathrm{IV})$, and organic matter and thereby influence water quality and taste (Lovley, 1997). It is likely that metal-reducing microorganisms inhabiting the $\mathrm{GAB}$ are responsible for boremetal corrosion, leading to bore failure causing significant water wastage and economic hardship to outback communities, who depend largely on this water resource. In this report, properties of a novel thermophilic, strictly anaerobic, $\mathrm{Fe}(\mathrm{III})$ - and $\mathrm{Mn}$ (IV)-reducing bacterium, designated strain $\mathrm{AeB}^{\mathrm{T}}$, which was isolated from brown-coloured microbial mats thriving in the New Lorne Bore run-off channel at $52{ }^{\circ} \mathrm{C}$, are described. Strain $\mathrm{AeB}^{\mathrm{T}}$ represents a novel species in a new genus, for which the name Fervidicella metallireducens gen. nov., sp. nov. is proposed.

The microbial mat sample used in this study was collected from the run-off channel of the New Lorne Bore situated near Blackall, some $1000 \mathrm{~km}$ north-west of Brisbane, QLD, Australia $\left(24^{\circ} 54^{\prime} 48^{\prime \prime} \mathrm{S} 145^{\circ} 08^{\prime} 18^{\prime \prime} \mathrm{E}\right)$. The bore was drilled in 1966 and has a depth of $1613 \mathrm{~m}$ and the temperature of the free-flowing water at the bore head was $88{ }^{\circ} \mathrm{C}$, with a pH of 8.5 and a flow rate of $7.61 \mathrm{l} \mathrm{s}^{-1}$ at the time of sampling. Iron and manganese concentrations of the free-flowing water were found to be $0.01 \mathrm{mg} \mathrm{l}^{-1}$. The brown-coloured microbial mats that thrived at $52{ }^{\circ} \mathrm{C}$ were collected in sterile glass vessels and the vessels were filled to the brim with water from the run-off channel, capped, transported to the laboratory and stored at $4{ }^{\circ} \mathrm{C}$ until used. The microbial mats have been described by Spanevello et al. (2002).

Enrichments were performed in APL medium amended with yeast extract $(0.2 \%)$. APL medium contained [(1 deionized water) ${ }^{-1}$ ]: $1 \mathrm{~g} \mathrm{NH} \mathrm{NH}_{4} \mathrm{Cl}, 0.6 \mathrm{~g} \mathrm{~K}_{2} \mathrm{HPO}_{4}, 0.3 \mathrm{~g}$ $\mathrm{KH}_{2} \mathrm{PO}_{4}, 0.1 \mathrm{~g} \mathrm{MgCl} .6 \mathrm{H}_{2} \mathrm{O}, 0.1 \mathrm{~g} \mathrm{CaCl} .2 \mathrm{H}_{2} \mathrm{O}, 1.0 \mathrm{~g}$ $\mathrm{NaCl}, 12.0 \mathrm{~g}$ HEPES, $1 \mathrm{ml}$ vitamin solution (Wolin et al., 1963), $1 \mathrm{ml}$ trace element solution (Zeikus et al., 1979), $1 \mathrm{ml} 0.2 \%$ resazurin, $0.2 \mathrm{~g}$ yeast extract and $2.0 \mathrm{~g}$ ammonium iron(III) citrate (brown). The $\mathrm{pH}$ of the medium was adjusted to 7.2 with $1 \mathrm{M} \mathrm{NaOH}$ and $1 \mathrm{M}$ $\mathrm{HCl}$. APL medium $(9.5 \mathrm{ml}$ ) was distributed in McCartney bottles and autoclaved for $30 \mathrm{~min}$ at $121{ }^{\circ} \mathrm{C}$ and 1.0 $1.5 \mathrm{~kg} \mathrm{~cm}^{-2}$ pressure. When APL medium was rendered anoxic, the medium was designated PL medium. Anoxic conditions were achieved by heating the medium for $10 \mathrm{~min}$ in an autoclave at $121^{\circ} \mathrm{C}$ and $1.0-1.5 \mathrm{~kg} \mathrm{~cm}^{-2}$ pressure to remove dissolved oxygen and the medium was subsequently cooled under a stream of oxygen-free nitrogen gas. Vitamins and trace elements were added and
$9.3 \mathrm{ml}$ medium was dispensed into Hungate tubes under oxygen-free nitrogen gas and sterilized for $20 \mathrm{~min}$ at $121{ }^{\circ} \mathrm{C}$ and $1.0-1.5 \mathrm{~kg} \mathrm{~cm}^{-2}$ pressure.

Enrichments were initiated in three different types of medium: APL medium (aerobic medium), PL medium (anaerobic medium), and PL medium minus ammonium iron(III) citrate, but amended with $3.0 \mathrm{~g}$ amorphous iron(III) oxyhydroxide $1^{-1}$ (Lovley \& Phillips, 1986). All media were amended with yeast extract $(0.2 \%)$ as an electron donor and were initiated by adding $500 \mu$ brown mat sample to $9.5 \mathrm{ml}$ medium and incubating at $50{ }^{\circ} \mathrm{C}$. Enrichment in APL medium (enrichment culture 1) was performed in an attempt to cultivate microaerophilic or facultative anaerobic $\mathrm{Fe}(\mathrm{III})$-reducing micro-organisms and, after 3 days incubation, a slimy surface layer was observed in the upper portion of the APL medium enrichment culture, suggesting that aerobic growth had occurred, and the reddish-brown colour of the APL medium had transformed into a colourless medium containing a dark precipitate [Fe(II)], suggesting $\mathrm{Fe}(\mathrm{III})$ reduction. On inversion of enrichment culture 1 , the colourless medium changed to a pink colour, signifying that, prior to the inversion, the medium had reached anoxic conditions. An attempt to isolate the Fe(III)reducing micro-organism from the APL enrichment culture by subculturing ( $5 \%)$ into anaerobically prepared PL medium amended with yeast extract $(0.2 \%)$ failed; however, $\mathrm{Fe}(\mathrm{III})$ reduction was observed when subcultured into PL medium amended with Casamino acids $(0.2 \%)$ after 3 days incubation at $50{ }^{\circ} \mathrm{C}$. This culture was serially diluted, incubated under the same conditions and the tube containing the lowest serial dilution $\left(10^{-4}\right)$ was selected; the procedure was repeated at least three times before a strain, designated $\mathrm{AeB}^{\mathrm{T}}$, was isolated and deemed to be a pure culture. Purity of the strain was subsequently confirmed by microscopy, subcultures on other substrates, including sugars, and $16 \mathrm{~S}$ rRNA gene sequencing. To identify the dominant aerobe within enrichment culture 1 , the initial enrichment was subcultured (5\%) in $9.5 \mathrm{ml}$ medium D (Brock \& Freeze, 1969) and incubated at $50{ }^{\circ} \mathrm{C}$ for 2 days. Repeat serial dilutions were performed as described above and a strain designated $A e B M D^{T}$ was isolated and deemed to be a pure culture. Partial 16S rRNA gene sequencing of $1327 \mathrm{nt}$ revealed that strain AeBMD ${ }^{\mathrm{T}}$ was related closely to Anoxybacillus flavithermus clone LK4 (GenBank accession no. EU816689; 99.1\% similarity) and so no further studies were performed on this strain.

$\mathrm{Fe}$ (III) reduction was observed after 2 days incubation in both enrichment culture 2 (PL medium) and enrichment culture 3 [PL medium minus ammonium iron(III) citrate, but amended with $3.0 \mathrm{~g}$ amorphous iron(III) oxyhydroxide $1^{-1}$ ]. Repeat serial dilutions were performed on both enrichment cultures as described above and a strain designated strain $\mathrm{B} 2-1^{\mathrm{T}}$ was isolated from enrichment culture 2 and deemed to be a pure culture. The isolation and subsequent characterization of strain $\mathrm{B} 2-\mathrm{1}^{\mathrm{T}}$ have been reported previously (Ogg \& Patel, 2009b) and the strain 
was designated Thermotalea metallivorans gen. nov., sp. nov. Repeat subcultures in dilution of enrichment culture 3 failed to isolate a pure culture, and so PL medium fortified with $0.2 \%$ yeast extract and $1 \%$ Gelrite was inoculated with $0.1 \mathrm{ml}$ of the lowest positive dilution $\left(10^{-4}\right.$ dilution $)$ taken from enrichment culture 3. Colonies developed after 4 days incubation at $50{ }^{\circ} \mathrm{C}$; they were picked and subcultured in PL medium minus ammonium iron(III) citrate amended with amorphous iron(III) oxyhydroxide and yeast extract $(0.2 \%)$. This isolate was designated $\mathrm{B} 150^{\mathrm{T}}$ and partial 16S rRNA gene sequencing of $765 \mathrm{nt}$ revealed that strain $\mathrm{B} 150^{\mathrm{T}}$ was identical $(99.8 \%)$ to strain $\mathrm{AeB}^{\mathrm{T}}$ and so no further characterization studies have been performed as yet. All pure cultures were stored in a glycerol/medium (50:50) mixture at $-20{ }^{\circ} \mathrm{C}$.

Strain $\mathrm{AeB}^{\mathrm{T}}$ was not able to grow under aerobic conditions in medium D (Brock \& Freeze, 1969). This result demonstrates the failure of the above enrichment strategy to cultivate facultative $\mathrm{Fe}$ (III)-reducing micro-organisms and concurs with previous enrichment attempts using this strategy (Ogg \& Patel, 2009d).

Cell morphology of strain $\mathrm{AeB}^{\mathrm{T}}$ was determined by phasecontrast microscopy and by electron microscopy (Kanso \& Patel, 2003). Cells of strain $\mathrm{AeB}^{\mathrm{T}}$ were peritrichously flagellated, slightly curved rods $(2.5-6.0 \times 1.0 \mu \mathrm{m})$ that existed singly, in pairs and in small chains. Cells of strain $\mathrm{AeB}^{\mathrm{T}}$ stained Gram-negative and electron micrographs of thin sections confirmed a Gram-negative cell-wall ultrastructure consisting of an inner electron-dense layer

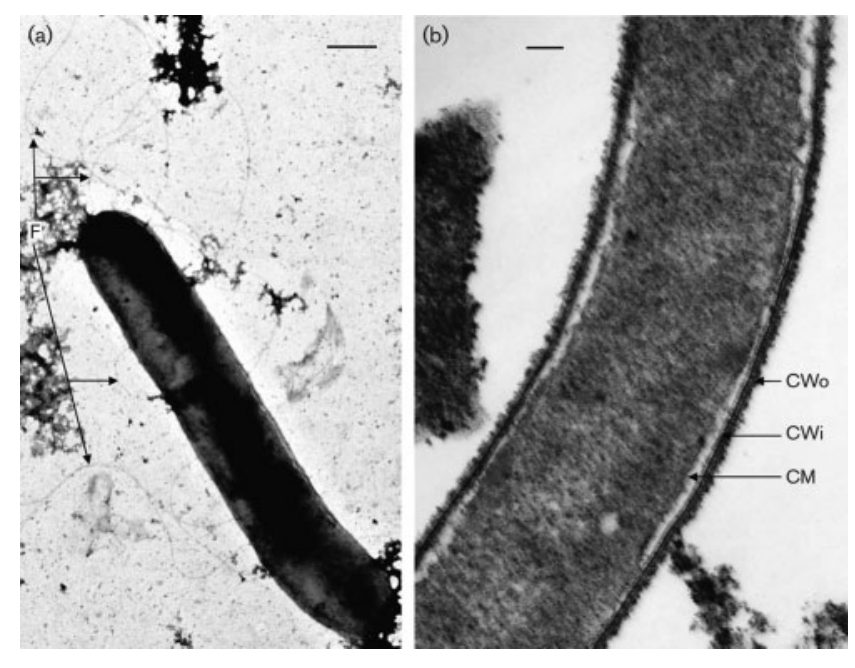

Fig. 1. Electron micrographs of cells of strain $A B^{\top}$. (a) Negatively stained cells showing a peritrichously flagellated cell. F, Flagella. Bar, $500 \mathrm{~nm}$. (b) Transmission electron micrograph of a thin section showing cell-wall ultrastructure revealing the presence of a cytoplasmic membrane (CM), an electron-dense wall layer adjacent to the membrane $(\mathrm{CWi})$ and an electron-light outer cell-wall layer composed of regular subunits (CWo). Bar, $100 \mathrm{~nm}$. adjacent to the cell membrane and an outer electron-light layer consisting of regular protein subunits (Fig. 1).

Cells of strain $\mathrm{AeB}^{\mathrm{T}}$ could be subcultured into tryptoneyeast extract-Casamino acids (TYECas) medium after 20 min heating at $95{ }^{\circ} \mathrm{C}$, but not after $30 \mathrm{~min}$. Spherical terminal and subterminal spores were detected in deathphase cultures. Using the method of Ogg \& Patel (2009a), a primer pair, forward GGI $(\mathrm{A} / \mathrm{G}) \mathrm{TICCIGCICA}(\mathrm{C} / \mathrm{T})$ $\mathrm{AT}(\mathrm{A} / \mathrm{T} / \mathrm{C}) \mathrm{AA}(\mathrm{A} / \mathrm{G}) \mathrm{GGITA}$ and reverse CATIGC(G/A/ T)AT(A/G)AA(C/T)TCI(G/C)(A/T)(A/G)TTIGTIGG(C/ T)TT (Brown et al., 1994), was used to amplify a $270 \mathrm{bp}$ fragment of the sporulation spo0A gene. Sequencing and sequence analysis indicated that the amplicon was related to the spo0A genes of Clostridium botulinum B strain Eklund 17B (GenBank accession no. CP001056), Clostridium acetobutylicum ATCC 824 ${ }^{\mathrm{T}}$, (GenBank accession no. AE001437.1) and Clostridium butyricum ATCC $19398^{\mathrm{T}}$ (GenBank accession no. U09980.1) with a similarity value of $80 \%$.

Unless otherwise indicated, all growth experiments were conducted at least twice and cultures were subcultured at least once in the same medium prior to the conduct of the experiment. Growth studies of strain $\mathrm{AeB}^{\mathrm{T}}$ were tested in anaerobic TYECas medium (modified TYEG medium), which consisted of low-phosphate-buffered salts (LPBS) amended with $0.2 \%$ each of tryptone, yeast extract and Casamino acids. LPBS was prepared anaerobically as described previously (Patel et al., 1985a, b) and contained [(1 deionized water $)^{-1}$ ]: $0.2 \mathrm{~g} \mathrm{MgCl}_{2} .6 \mathrm{H}_{2} \mathrm{O}, 0.9 \mathrm{~g} \mathrm{NH}_{4} \mathrm{Cl}$, $0.75 \mathrm{~g} \mathrm{KH}_{2} \mathrm{PO}_{4}, 1.5 \mathrm{~g} \mathrm{~K}_{2} \mathrm{HPO}_{4}, 1.0 \mathrm{~g} \mathrm{NaCl}, 5 \mu \mathrm{l} 10 \%$ $\mathrm{FeSO}_{4}, 9 \mathrm{ml}$ trace element solution (Zeikus et al., 1979), $5 \mathrm{ml}$ vitamin solution (Wolin et al., 1963), $1 \mathrm{ml} 0.2 \%$ resazurin and $2 \mathrm{ml} 10 \% \mathrm{Na}_{2} \mathrm{~S} .9 \mathrm{H}_{2} \mathrm{O}$. Growth of strain $\mathrm{AeB}^{\mathrm{T}}$ was tested at temperatures ranging from 26 to $70{ }^{\circ} \mathrm{C}$ and $\mathrm{pH}$ values ranging from 4.5 to 9.5. Growth was measured at $580 \mathrm{~nm}$ by inserting Hungate tubes directly into a modified cuvette holder of a Novaspec LKB spectrophotometer (Pharmacia Biotech). Strain $A_{e B}{ }^{T}$ grew optimally in TYECas medium at $50{ }^{\circ} \mathrm{C}$ (range $37-55{ }^{\circ} \mathrm{C}$ ) and $\mathrm{pH} 7$ (range $\mathrm{pH} 5-9$ ), with a generation time of 46.4 min under these conditions. Unless indicated otherwise, all subsequent growth experiments were conducted under these conditions.

Strain $\mathrm{AeB}^{\mathrm{T}}$ was tested for its ability to grow in LPBS amended with $0.2 \%$ tryptone (medium $\mathrm{T}$ ), $0.2 \%$ yeast extract (medium YE) or $0.2 \%$ each of tryptone and yeast extract (medium TYE) as carbon sources and compared with growth in the complete TYECas medium. After $5 \mathrm{~h}$ incubation, growth of approximately 25, 50 and $100 \%$ was observed in the three media, respectively $\left(\mathrm{OD}_{580}\right.$ of $0.22=100 \%$ ). Furthermore, Casamino acids could not be used as the sole carbon source (medium Cas), but were utilized in the presence of tryptone (medium TCas) or yeast extract (medium YECas). Under these conditions, growth reached levels of 75 and $85 \%$ in TCas and YECas, respectively, after $5 \mathrm{~h}$ incubation. When the yeast extract 
concentration in YECas medium was lowered to 0.02, 0.05 or $0.1 \%$, approximately 45,50 and $70 \%$ growth, respectively, was observed (compared with growth with $0.2 \%$ YECas medium), indicating that growth of strain $\mathrm{AeB}^{\mathrm{T}}$ was influenced by the components in yeast extract in a dose-dependent manner.

Substrate-utilization tests were performed in the presence of $0.02 \%$ yeast extract. Soluble substrates were added from sterile anaerobic stock solutions to a final concentration of $0.2 \%$ to sterile YE $(0.02 \%)$ medium. Insoluble substrates were weighed directly into Hungate tubes, YE $(0.02 \%)$ medium was dispensed and the medium was sterilized. Growth was measured hourly at $580 \mathrm{~nm}$ until stationary phase was reached. Cultures containing no added substrates were used as negative controls and tubes containing Casamino acids $(0.2 \%)$ were used as positive controls Growth was observed with peptone, glucose (approximate generation time of $36.2 \mathrm{~min}$ ), sucrose, fructose, maltose, mannitol, starch, pectin, pyruvate, amyl media, Casamino acids (approximate generation time of $157.2 \mathrm{~min}$ ), methionine, serine and threonine, but not galactose, mannose, lactose, cellobiose, rhamnose, arabinose, raffinose, inositol, glycerol, ethanol, formate, acetate, propionate, lactate, aspartate, succinate, glycine (both in the presence and absence of uric acid), adenine, guanine, uric acid, caffeine, purine, valine, leucine, alanine, methionine, isoleucine, arginine or histidine.

End products from glucose fermentation were determined in a culture grown in YE medium amended with glucose $(0.2 \%)$ as described previously (Chrisostomos et al., 1996; Ogg \& Patel, 2009a). End products from glucose fermentation were ethanol, acetate, $\mathrm{CO}_{2}$ and $\mathrm{H}_{2}$.

To determine the substrates used by strain $\mathrm{AeB}^{\mathrm{T}}$ with reduction of $\mathrm{Fe}(\mathrm{III})$, substrates were added to PL medium and cultures were incubated for up to 8 days at $50{ }^{\circ} \mathrm{C}$. $\mathrm{Fe}$ (III) reduction was inferred when transformation of the reddish-brown colour of the $\mathrm{Fe}(\mathrm{III})$ to a dark precipitate $[\mathrm{Fe}(\mathrm{II})]$ and clearing of the medium were observed. $\mathrm{Fe}(\mathrm{III})$ reduction was confirmed by measuring $\mathrm{Fe}(\mathrm{II})$ accumulation using the ferrozine method (Sørensen, 1982). A $0.1 \mathrm{ml}$ sample was mixed with $3 \mathrm{ml}$ ferrozine reagent and, after $1 \mathrm{~min}, A_{562}$ was determined. A culture containing PL medium lacking a substrate was used as a negative control and a culture containing PL medium amended with $2 \mathrm{~g}$ Casamino acids $1^{-1}$ was used as a positive control. Fe(III) reduction can occur spontaneously in the presence of carbohydrates under sterile conditions (Zavarzina et al., 2002) and, hence, most carbohydrates were not tested. $\mathrm{Fe}(\mathrm{III})$ was reduced in the presence of yeast extract, tryptone, peptone and amyl media, but not with starch, xylan, chitin, glycerol, ethanol, pyruvate, benzoate, lactate, acetate, propionate, succinate, serine, lysine, threonine, arginine, glutamate, glycine, valine, leucine, histidine, alanine, aspartate, isoleucine or methionine. Given that $\mathrm{Fe}(\mathrm{III})$ was only reduced in the presence of substrates that could be fermented, an investigation to determine whether energy is conserved to support growth from the reduction of $\mathrm{Fe}(\mathrm{III})$ to $\mathrm{Fe}(\mathrm{II})$ was deemed to be equivocal.

The ability of strain $\mathrm{AeB}^{\mathrm{T}}$ to utilize $\mathrm{H}_{2}$ and $\mathrm{CO}_{2}$ in the presence and absence of $\mathrm{Fe}(\mathrm{III})$ was tested in $60 \mathrm{ml}$ serum bottles that contained $15 \mathrm{ml} \mathrm{PL}$ medium and $\mathrm{H}_{2} / \mathrm{CO}_{2}$ gas mixture $(5: 95$ or $10: 90, \mathrm{v} / \mathrm{v})$ or $\mathrm{CO}_{2}(100 \%)$. No growth or $\mathrm{Fe}(\mathrm{III})$ reduction was noted.

Electron acceptor-utilization tests for sodium thiosulfate $(20 \mathrm{mM})$, sodium sulfate $(20 \mathrm{mM})$, sodium sulfite (10 mM), elemental sulfur (1\%), sodium nitrate $(20 \mathrm{mM})$ and sodium nitrite $(5 \mathrm{mM})$ were tested in YE medium as described by Ramamoorthy et al. (2006) and Ogg \& Patel (2009a). Reduction of $3 \mathrm{~g}$ amorphous iron(III) oxyhydroxide $\mathrm{l}^{-1}$ (Lovley \& Phillips, 1986), $2 \mathrm{~g}$ $\mathrm{MnO}_{2} \mathrm{l}^{-1}$ (Lovley \& Phillips, 1988), $4 \mathrm{mM}$ vanadium(V) and $5 \mathrm{mM}$ cobalt(III) was tested in PL medium amended with yeast extract $(0.2 \%)$, but lacking ammonium iron(III) citrate. $\mathrm{Fe}(\mathrm{III})$ reduction was determined as described above. $\mathrm{Mn}(\mathrm{IV})$ reduction was determined as described previously by Spratt et al. (1994) and Ogg \& Patel (2009a). $\mathrm{V}(\mathrm{V})$ reduction was inferred from a medium colour change to green and/or a green precipitate formed in the medium and was confirmed using the vanadate assay as described by Carpentier et al. (2003). For this, $250 \mu \mathrm{l} 1 \%$ (w/v) diphenylcarbazide in acetone was added to $250 \mu \mathrm{l} 2 \mathrm{M}$ $\mathrm{H}_{2} \mathrm{SO}_{4}$, which was combined with $500 \mu \mathrm{l}$ diluted sample and the $A_{320}$ was measured after $15 \mathrm{~min}$. Co(III) reduction was scored as positive when a medium colour change from purple $[\mathrm{Co}(\mathrm{III})]$ to clear was observed. In the presence of yeast extract $(0.2 \%)$, strain $\mathrm{AeB}^{\mathrm{T}}$ was able to reduce amorphous iron(III) oxyhydroxide, $\mathrm{Mn}(\mathrm{IV}), \mathrm{V}(\mathrm{V})$ and $\mathrm{Co}(\mathrm{III})$, but not elemental sulfur, sulfate, thiosulfate, sulfite, nitrate or nitrite.

Antibiotic sensitivity was determined by adding antibiotics from filter-sterilized stock solutions to sterilized TYECas medium to final concentrations of 10 and $100 \mu \mathrm{g} \mathrm{ml}^{-1}$. Growth inhibition of each antibiotic was calculated from final turbidity measurements of cultures that had been grown in antibiotic-free TYECas medium and growth was expressed as percentage inhibition. Strain $\mathrm{AeB}^{\mathrm{T}}$ was inhibited completely in the presence of ampicillin, streptomycin, tetracycline, penicillin and chloramphenicol (all at $10 \mu \mathrm{g} \mathrm{ml}^{-1}$ ). The effect of $\mathrm{NaCl}$ on growth of strain $\mathrm{AeB}^{\mathrm{T}}$ was determined; $\mathrm{NaCl}$ was added directly to Hungate tubes at concentrations of $0,0.01$ and $1-5 \%$, the TYECas medium was dispensed and the medium was sterilized. Strain $\mathrm{AeB}^{\mathrm{T}}$ was able to grow without $\mathrm{NaCl}$, but not at concentrations $>2 \%$. Reduced growth was observed at $\mathrm{NaCl}$ concentrations $>0.1 \%$.

The DNA G $+\mathrm{C}$ content of strain $\mathrm{AeB}^{\mathrm{T}}$ was determined by the thermal denaturation method (Marmur \& Doty, 1962) in a Cintra20 spectrophotometer (GBC Scientific Equipment) with DNA that had been amplified using a TempliPhi Amplification kit (Amersham Biosciences) as described by Ogg \& Patel (2009a). The G + C content of the genomic DNA was calculated to be $35.4 \pm 1 \mathrm{~mol} \%$. 
$16 \mathrm{~S}$ rRNA gene amplification, sequencing and analysis were performed using the method of Ogg \& Patel (2009a). Phylogenetic analysis of the consensus $16 \mathrm{~S}$ rRNA gene sequence, comprising $1423 \mathrm{nt}$, indicated that strain $\mathrm{AeB}^{\mathrm{T}}$ was a member of the family Clostridiaceae, class Clostridia, phylum 'Firmicutes', and is positioned approximately equidistantly between the genera Sarcina, Anaerobacter, Caloramator and Clostridium (16S rRNA gene sequence similarity values of $87.8-90.9 \%$ ) (Fig. 2). The closest relatives to strain $\mathrm{AeB}^{\mathrm{T}}$ included Clostridium cylindrosporum DSM $605^{\mathrm{T}}$ ( $90.9 \%$ similarity), which is known to inhabit various soils and chicken intestines (Andreesen et al., 1985), and Caloramator viterbiensis DSM $13723^{\mathrm{T}}$ (90.7\% similarity), which inhabits hot-spring environments (Seyfried et al., 2002). Phenotypically, strain $A_{e B}{ }^{T}$ could be differentiated from both of these strains by its morphology, negative Gram stain, G + C content, optimal growth conditions and nutritional spectrum (Table 1). Interestingly, strain $\mathrm{AeB}^{\mathrm{T}}$ possessed more phenotypic characteristics in common with Caloramator viterbiensis than with Clostridium cylindrosporum, including thermophilic growth, carbohydrate fermentation, the inability to reduce sulfate, elemental sulfur and nitrate, and the utilization of yeast extract, glucose, sucrose, fructose, starch, serine and threonine, but not arabinose, ethanol or organic acids. However, strain $\mathrm{AeB}^{\mathrm{T}}$ could be further differentiated from Caloramator viterbiensis by its ability to reduce $\mathrm{Fe}(\mathrm{III})$ and its inability to utilize galactose, mannose, lactose, cellobiose, glycerol, aspartate, leucine and histidine. Strain $\mathrm{AeB}^{\mathrm{T}}$ could be further differentiated from Clostridium cylindrosporum by its ability to ferment carbohydrates and serine, but not glycine, uric acid or guanine. Based on the phenotypic differences and the large phylogenetic distance separating strain $\mathrm{AeB}^{\mathrm{T}}$ from other members of the family Clostridiaceae, a novel species in a new genus, Fervidicella metallireducens gen. nov., sp. nov., is proposed to accommodate this newly described strain.

\section{Description of Fervidicella gen. nov.}

Fervidicella (Fer.vi.di.cel'la. L. adj. fervidus glowing, hot, burning; L. fem. n. cella a storeroom, chamber, and, in biology, a cell; N.L. fem. n. Fervidicella a glowing cell, a thermophile).

Cells are strictly anaerobic, slightly curved rods. Gram reaction is negative. Cells possess peritrichous flagella. Spherical terminal to subterminal spores are formed. $16 \mathrm{~S}$ rRNA gene analysis indicates that the genus is a member of the family Clostridiaceae, approximately equidistant between the genera Sarcina, Anaerobacter, Caloramator and Clostridium (87.8-90.9\% 16S rRNA gene sequence similarity). The type species and the sole member of this genus is Fervidicella metallireducens.

\section{Description of Fervidicella metallireducens sp. nov.}

Fervidicella metallireducens (me.tal'li.re.du'cens. L. n. metallum metal; L. part. adj. reducens leading back, bringing back, and, in chemistry, converting to a different oxidation state; N.L. part. adj. metallireducens reducing metal).

Cells are 2.5-6.0 $\times 1.0 \mu \mathrm{m}$. Growth occurs between 37 and $55{ }^{\circ} \mathrm{C}$ (optimum temperature $50{ }^{\circ} \mathrm{C}$ ) and at $\mathrm{pH}$ 5-9 (optimum pH 7). Grows on yeast extract and tryptone as sole carbon sources. Yeast extract or tryptone is required for growth with other substrates. Utilizes peptone, glucose, sucrose, fructose, maltose, mannitol, starch, pectin, pyruvate, amyl media, Casamino acids, methionine, serine and threonine, but not galactose, mannose, lactose, cellobiose, rhamnose, raffinose, arabinose, inositol, glycerol, ethanol, formate, acetate, propionate, lactate, aspartate, succinate, glycine, adenine, guanine, uric acid, caffeine, purine, leucine, alanine, isoleucine, arginine, histidine or $\mathrm{H}_{2} / \mathrm{CO}_{2}$. End products from glucose fermentation are ethanol, acetate, $\mathrm{CO}_{2}$ and $\mathrm{H}_{2}$. $\mathrm{Fe}(\mathrm{III}), \mathrm{Mn}(\mathrm{IV}), \mathrm{V}(\mathrm{V})$ and $\mathrm{Co}(\mathrm{III})$ are reduced in the presence of yeast extract, but not elemental sulfur, sulfate, sulfite, thiosulfate, nitrate or nitrite. Fe(III) is also reduced in the presence of tryptone, peptone, Casamino acids and amyl media, but not starch, xylan, chitin, glycerol, ethanol, pyruvate, benzoate, lactate, acetate, propionate, succinate, glycine, serine, lysine,

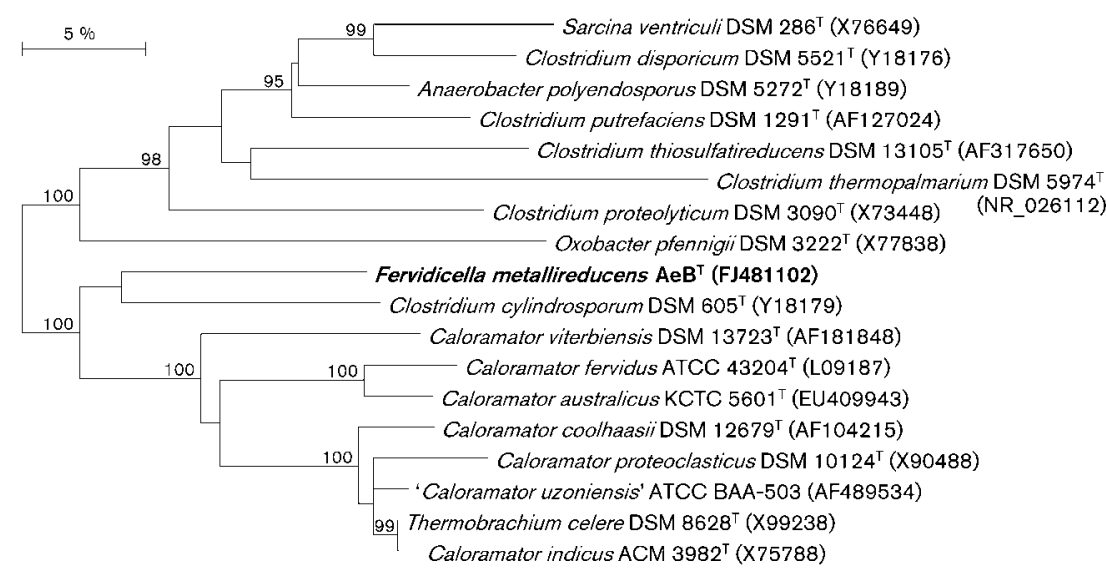

Fig. 2. Dendrogram showing the phylogenetic position of Fervidicella metallireducens $\mathrm{AeB}^{\top}$ and its closest relatives. GenBank accession numbers are given in parentheses. Bootstrap values $>95 \%$ are shown. Bar, 5 nucleotide changes per $100 \mathrm{nt}$. 
Table 1. Selected characteristics of Fervidicella metallireducens $\mathrm{AeB}^{\top}$ and closely related strains

Strains: 1, Fervidicella metallireducens $\mathrm{AeB}^{\mathrm{T}} ; 2$, Clostridium cylindrosporum DSM $605^{\mathrm{T}}$ (Andreesen et al., 1985); 3, Caloramator viterbiensis DSM $13723^{\mathrm{T}}$ (Seyfried et al., 2002). +, Positive; -, negative; ND, not determined.

\begin{tabular}{|c|c|c|c|}
\hline Characteristic & 1 & 2 & 3 \\
\hline Isolation source & $\begin{array}{l}\text { Microbial mats from a thermal aquifer } \\
\text { bore outflow }\end{array}$ & $\begin{array}{l}\text { Soil and chicken } \\
\text { intestines }\end{array}$ & Hot springs \\
\hline Morphology & Slightly curved rods & Straight rods & Straight to slightly curved rods \\
\hline Cell width $(\mu \mathrm{m})$ & 1.0 & 0.8 & $0.4-0.6$ \\
\hline Cell length $(\mu \mathrm{m})$ & $2.5-6.0$ & 3.3 & $2.0-3.0$ \\
\hline Cell-wall ultrastructure & - & $-\dagger$ & + \\
\hline Sporulation & - & + & - \\
\hline Motility & + & + & - \\
\hline \multicolumn{4}{|l|}{ Growth temperature $\left({ }^{\circ} \mathrm{C}\right)$ : } \\
\hline Optimum & 50 & $40-45$ & 58 \\
\hline Range & $30-55$ & 19 to $\mathrm{ND}$ & $33-64$ \\
\hline \multicolumn{4}{|l|}{ Nutritional characteristics } \\
\hline \multicolumn{4}{|l|}{ Carbohydrate fermentation: } \\
\hline Fructose & + & - & + \\
\hline Starch & + & - & + \\
\hline Glucose & + & - & + \\
\hline Galactose & - & ND & + \\
\hline Mannose & - & ND & + \\
\hline Lactose & - & $\mathrm{ND}$ & + \\
\hline Cellobiose & - & ND & + \\
\hline \multicolumn{4}{|l|}{ Alcohol fermentation: } \\
\hline Glycerol & - & ND & + \\
\hline Histidine & - & $\mathrm{ND}$ & + \\
\hline $\mathrm{Fe}(\mathrm{III})$ reduction & + & ND & - \\
\hline $\begin{array}{l}\text { 16S rRNA gene sequence similarity to } \\
\text { strain } \mathrm{AeB}^{\mathrm{T}}(\%)\end{array}$ & 100 & 91.0 & 90.7 \\
\hline
\end{tabular}

* Only actively growing cultures stain Gram-positive.

$\dagger$ Data from Dürre et al. (1981).

$\neq \mathrm{pH}$ optimum changes with different substrates.

$\S$ In the presence of uric acid.

threonine, arginine, glutamate, valine, leucine, histidine, alanine, aspartate, isoleucine, methionine or $\mathrm{H}_{2} / \mathrm{CO}_{2}$. Sensitive to chloramphenicol, streptomycin, tetracycline, penicillin, ampicillin and $\mathrm{NaCl}$ concentrations $>2 \%$.

The type strain is $\mathrm{AeB}^{\mathrm{T}}\left(=\mathrm{KCTC} 5667^{\mathrm{T}}=\mathrm{JCM} 15555^{\mathrm{T}}\right.$ ), isolated from a microbial mat sample from the outflow of a
Great Artesian Basin bore (the New Lorne Bore) in Queensland, Australia. The G $+\mathrm{C}$ content of the genomic DNA of the type strain is $35.4 \pm 1$ mol\%. Phylogenetically related to Clostridium cylindrosporum DSM 605 ${ }^{\mathrm{T}}(90.9 \%$ $16 \mathrm{~S}$ rRNA gene sequence similarity) and Caloramator viterbiensis DSM $13723^{\mathrm{T}}$ (90.7\% 16S rRNA gene sequence similarity). 


\section{References}

Andreesen, J. R., Zindel, U. \& Dürre, P. (1985). Clostridium cylindrosporum (ex Barker and Beck 1942) nom. rev. Int J Syst Bacteriol 35, 206-208.

Brock, T. D. \& Freeze, H. (1969). Thermus aquaticus gen. nov., a nonsporulating extreme thermophile. J Bacteriol 98, 289-297.

Brown, D. P., Genova-Raeva, L., Green, B. D., Wilkinson, S. R., Young, M. \& Youngman, P. (1994). Characterization of spo0A homologues in diverse Bacillus and Clostridium species identifies a probable DNA-binding domain. Mol Microbiol 14, 411-426.

Carpentier, W., Sandra, K., De Smet, I., Brigé, A., De Smet, L. \& Van Beeumen, J. (2003). Microbial reduction and precipitation of vanadium by Shewanella oneidensis. Appl Environ Microbiol 69, 3636-3639.

Chrisostomos, S., Patel, B. K. C., Dwivedi, P. P. \& Denman, S. E. (1996). Caloramator indicus sp. nov., a new thermophilic anaerobic bacterium isolated from the deep-seated nonvolcanically heated waters of an Indian artesian aquifer. Int J Syst Bacteriol 46, 497-501.

Dürre, P., Andersch, W. \& Andreesen, J. R. (1981). Isolation and characterisation of an adenine-utilizing anaerobic sporeformer, Clostridium purinolyticum sp. nov. Int J Syst Bacteriol 31, 184-194.

Habermehl, M. A. (1980). The Great Artesian Basin, Australia. BMR J Aust Geol Geophys 5, 9-38.

Kanso, S. \& Patel, B. K. C. (2003). Microvirga subterranea gen. nov., sp. nov., a moderate thermophile from a deep subsurface Australian thermal aquifer. Int J Syst Evol Microbiol 53, 401-406.

Lovley, D. R. (1997). Microbial Fe(III) reduction in subsurface environments. FEMS Microbiol Rev 20, 305-313.

Lovley, D. R. \& Phillips, E. J. P. (1986). Organic matter mineralization with reduction of ferric iron in anaerobic sediments. Appl Environ Microbiol 51, 683-689.

Lovley, D. R. \& Phillips, E. J. P. (1988). Novel mode of microbial energy metabolism: organic carbon oxidation coupled to dissimilatory reduction of iron or manganese. Appl Environ Microbiol 54, 14721480.

Marmur, J. \& Doty, P. (1962). Determination of the base composition of deoxyribonucleic acid from its thermal denaturation temperature. J Mol Biol 5, 109-118.

Ogg, C. D. \& Patel, B. K. C. (2009a). Caloramator australicus sp. nov., a thermophilic anaerobic bacterium from the Great Artesian Basin of Australia. Int J Syst Evol Microbiol 59, 95-101.

Ogg, C. D. \& Patel, B. K. C. (2009b). Thermotalea metallivorans gen. nov., sp. nov., a thermophilic, anaerobic bacterium from the Great Artesian Basin of Australia aquifer. Int J Syst Evol Microbiol 59, 964971.

Ogg, C. D. \& Patel, B. K. C. (2009c). Fervidicola ferrireducens gen. nov., sp. nov., a thermophilic anaerobic bacterium from geothermal waters of the Great Artesian Basin, Australia. Int J Syst Evol Microbiol 59, 1100-1107.
Ogg, C. D. \& Patel, B. K. C. (2009d). Sporolituus thermophilus gen. nov., sp. nov., a citrate-fermenting thermophilic anaerobic bacterium from geothermal waters of the Great Artesian Basin of Australia. Int $J$ Syst Evol Microbiol 59, 2848-2853.

Ogg, C. D., Greene, A. C. \& Patel, B. K. C. (2010). Thermovenabulum gondwanense sp. nov., a thermophilic anaerobic $\mathrm{Fe}(\mathrm{III})$-reducing bacterium isolated from microbial mats thriving in a Great Artesian Basin bore runoff channel. Int J Syst Evol Microbiol 60, 1079-1084.

Patel, B. K. C., Morgan, H. W. \& Daniel, R. M. (1985a). A simple and efficient method for preparing and dispensing anaerobic media. Biotechnol Lett 7, 277-278.

Patel, B. K. C., Morgan, H. W. \& Daniel, R. M. (1985b). Fervidobacterium nodosum gen. nov. and spec. nov., a new chemoorganotrophic, caldoactive, anaerobic bacterium. Arch Microbiol 141, 63-69.

Ramamoorthy, S., Sass, H., Langner, H., Schumann, P., Kroppenstedt, R. M., Spring, S., Overmann, J. \& Rosenzweig, R. F. (2006). Desulfosporosinus lacus sp. nov., a sulfate-reducing bacterium isolated from pristine freshwater lake sediments. Int J Syst Evol Microbiol 56, 2729-2736.

Seyfried, M., Lyon, D., Rainey, F. A. \& Wiegel, J. (2002). Calormator viterbiensis sp. nov., a novel thermophilic, glycerol-fermenting bacterium isolated from a hot spring in Italy. Int $J$ Syst Evol Microbiol 52, 1177-1184.

Sørensen, J. (1982). Reduction of ferric iron in anaerobic, marine sediment and interaction with reduction of nitrate and sulfate. Appl Environ Microbiol 43, 319-324.

Spanevello, M. D. (2001). The phylogeny of prokaryotes associated with Australia's Great Artesian Basin. PhD thesis, School of Biomolecular and Physical Science, Griffith University, Brisbane, Australia.

Spanevello, M. D., Yamamoto, H. \& Patel, B. K. C. (2002). Thermaerobacter subterraneus sp. nov., a novel aerobic bacterium from the Great Artesian Basin of Australia, and emendation of the genus Thermaerobacter. Int J Syst Evol Microbiol 52, 795-800.

Spratt, H. G., Jr, Siekmann, E. C. \& Hodson, R. E. (1994). Microbial manganese oxidation in saltmarsh surface sediments using a leuco crystal violet manganese oxide detection technique. Estuar Coast Shelf Sci 38, 91-112.

Wolin, E. A., Wolin, M. J. \& Wolfe, R. S. (1963). Formation of methane by bacterial extracts. J Biol Chem 238, 2882-2886.

Zavarzina, D. G., Tourova, T. P., Kuznetsov, B. B., BonchOsomolovskaya, E. A. \& Slobodkin, A. I. (2002). Thermovenabulum ferriorganovorum gen. nov., sp. nov., a novel thermophilic, anaerobic, endospore-forming bacterium. Int J Syst Evol Microbiol 52, 17371743.

Zeikus, J. G., Hegge, P. W. \& Anderson, M. A. (1979). Thermoanaerobium brockii gen. nov. and sp. nov., a new chemoorganotrophic, caldoactive, anaerobic bacterium. Arch Microbiol 122, 4148. 